\title{
Effects of physical fragmentation on remineralization of marine snow
}

\author{
S. A. Goldthwait ${ }^{1,2, *}$, C. A. Carlson ${ }^{2}$, G. K. Henderson ${ }^{1,2}$, A. L. Alldredge ${ }^{2}$ \\ ${ }^{1}$ Virginia Institute of Marine Science, Department of Biological Science, PO Box 1346, Gloucester Point, Virginia 23062, USA \\ ${ }^{2}$ Department of Ecology, Evolution, and Marine Biology, University of California, Santa Barbara, California 93106, USA
}

\begin{abstract}
The vast majority of carbon lost from ocean surface waters sinks as large, relatively rare, marine snow and fecal pellets. Fragmentation of these particles into more slowly sinking daughter particles has been proposed previously to partly explain the rapid loss of sinking carbon below the mixed layer. In this study we investigated 2 other less obvious potential consequences of aggregate disruption, namely the release of dissolved interstitial compounds upon fragmentation and accelerated degradation due to increased particle surface area. We found that upon fragmentation natural marine aggregates, ranging in size from 3 to $6 \mathrm{~mm}$ diameter, released dissolved organic carbon (DOC) (mean $0.12 \mu \mathrm{mol}$ aggregate ${ }^{-1}$ ) and nitrate (mean of $0.013 \mu \mathrm{mol}_{\text {aggregate }}{ }^{-1}$ ) into surrounding seawater, making these nutrients available to free-living biota. Filtration of whole aggregates failed to result in an equivalent release, suggesting that marine snow may not be as leaky as expected based on high aggregate porosity. Decomposition of aggregate particulate organic carbon (POC) to DOC was similar for whole and fragmented aggregates ranging from 0.6 to $0.9 \mu \mathrm{mol}$ POC aggregate $^{-1} \mathrm{~d}^{-1}$, resulting in calculated aggregate POC turnover times of 2 to $11 \mathrm{~d}$. Remineralization of DOC was also similar for both aggregate treatments and suggested a tight coupling between solubilization and uptake by attached bacteria. Our results indicate that the longer residence times predicted for smaller aggregates in the mixed layer, rather than changes in decomposition rate, may be the most influential impact of aggregate fragmentation on reduction of particle flux to depth.
\end{abstract}

KEY WORDS: Marine snow · Fragmentation · Disaggregation · Solubilization · Remineralization · Attached bacteria

\section{INTRODUCTION}

Fragmentation was proposed by Karl et al. (1988) to be one of several potentially important mechanisms by which sinking macroaggregates are lost in ocean surface waters. Understanding the reduction of particle flux beneath the mixed layer (Martin et al. 1987) has important consequences for our understanding of the biological pump and the functioning of organisms living in the mesopelagic zone where aggregates comprise a major carbon $(\mathrm{C})$ source and an important habitat. In the natural environment, macroaggregates or marine snow (aggregates $>0.5 \mathrm{~mm}$ ) can probably be fragmented via a variety of processes, including abiotic shear stress due to wind or convection (Karl et al. 1988,
Ruiz 1997), biotic shear stress resulting from zooplankton swimming and feeding (Steinberg et al. 1997, Dilling \& Alldredge 2000, Goldthwait et al. 2004), sloppy feeding on aggregates (Banse 1995) and fecal pellets (Lampitt et al. 1990), and burrowing (Steinberg et al. 1997) and solubilization (e.g. Smith et al. 1992) by aggregate-associated biota.

There are several potential consequences of these aggregate-disrupting processes. The most obvious result is that the daughter particles produced should sink more slowly than the original parent particle due to a reduction in size without a change in composition (Alldredge \& Gotschalk 1988). Slower sinking rates mean that daughter particles will have longer residence times in surface waters, increasing the likelihood of aggre- 
gate remineralization and $\mathrm{C}$ retention in the mixed layer. This study tested 2 less obvious consequences of fragmentation for the first time: (1) the immediate release of dissolved organic carbon (DOC) and interstitial nutrients into surrounding seawater, and (2) elevated solubilization and remineralization of daughter-particle $\mathrm{C}$ due to increased available surface area for bacterial colonization. Both of these processes would also serve to reduce total $\mathrm{C}$ flux, but their magnitude and significance have not been previously determined.

In this study, we collected natural aggregates of marine snow in the Santa Barbara Channel, California, and physically fragmented a subset of them. The potential release of interstitial DOC and nutrients into surrounding seawater was assessed immediately following aggregate fragmentation. Then, in 2 separate experiments, we compared solubilization and remineralization for whole versus fragmented aggregates by assessing changes over time in the pools of organic carbon (particulate organic carbon [POC], DOC, total organic carbon [TOC]). Aggregate $\mathrm{C}$ degradation has traditionally been assessed by indirect methods such as measuring oxygen gradients, ectoenzyme activity, or attached bacterial production (e.g. Smith et al. 1992, Unanue et al. 1998, Ploug \& Grossart 2000). This is the first study to simultaneously and directly track POC and DOC in controlled bottle incubations allowing us to monitor both solubilization and remineralization of aggregate $\mathrm{C}$ using a mass balance approach. Our goal was to assess the consequences of fragmentation on the chemical environment of the aggregate and on aggregate degradation by attached and free-living biota. As aggregate fragmentation may be one of the primary removal mechanisms for sinking particles, it is critical to characterize the biogeochemical outcome of this process and its role in $\mathrm{C}$ cycling in the ocean.

\section{MATERIALS AND METHODS}

Collection of marine snow aggregates. Natural marine snow was collected by SCUBA divers in the surface waters (13 to $20 \mathrm{~m}$ ) of the Santa Barbara Channel, California $\left(34^{\circ} 17^{\prime} \mathrm{N}, 119^{\circ} 53^{\prime} \mathrm{W}\right)$ in the summers of 2002 and 2003. Individual aggregates were sampled with acid-rinsed $8 \mathrm{ml}$ polypropylene syringes modified by cutting off the syringe tip to create a uniform cylinder stoppered on either end with a plunger fitted with a silicone o-ring (see Alldredge 1993). A single marine snow aggregate was gently drawn into each syringe along with 2 to $3 \mathrm{ml}$ of surrounding seawater. During each dive, 200 to 300 aggregates of roughly the same size were collected. Prior to starting the experiments, the syringes and seawater samples were stored at sea surface temperature for a maximum of $6 \mathrm{~h}$.
For all experiments there were 2 aggregate treatments ('whole' and 'fragmented') and a seawater control. 'Whole' aggregates were gently removed from the collection syringe with a wide-bore pipette. For 'fragmented' treatments, aggregates were disaggregated within the collection chamber by drawing the syringe contents rapidly into and out of a wide-bore pipette 10 times without introducing any air. This method resulted in several separate and visible daughter particles and did not damage cell-wall integrity (Gotschalk \& Alldredge 1989). Aggregate-free controls involved the addition of aggregate-free seawater collected in a $250 \mathrm{ml}$ polypropylene bottle by a diver at the same time and depth at which the aggregates were sampled. Each of the experiments described below was conducted on a different day with only aggregates freshly collected on that day. For each experiment aggregate dry mass was determined, whereby 15 to 20 aggregates were filtered individually onto preweighed $0.4 \mu \mathrm{m}, 25 \mathrm{~mm}$ Poretics polycarbonate filters, gently rinsed with deionized water, and dried at $60^{\circ} \mathrm{C}$ before being reweighed on a Model 4600 Cahn Electrobalance.

Fragmentation experiment. The fragmentation experiment was designed to test for the immediate release of interstitial nutrients and DOC as a result of aggregate disruption. We filled 11 glass-stoppered BOD bottles $(300 \mathrm{ml})$ with unfiltered seawater collected from the dive depth $(20 \mathrm{~m})$ with a Niskin bottle rosette, and 10 aggregates were added to each of 4 replicates for the whole and fragmented aggregate treatments. Aggregate-free seawater from the dive depth was used to simulate 10 aggregate additions to each of 3 replicate control bottles. The contents of each bottle were then immediately filtered through a combusted $47 \mathrm{~mm}$ GF/F filter at a vacuum pressure of 100 to $150 \mathrm{~mm} \mathrm{Hg}$ to collect the particles. These filters were stored in precombusted aluminum foil at $-20^{\circ} \mathrm{C}$ prior to being dried and analyzed for POC and particulate organic nitrogen (PON) content. Samples were analyzed (after Sharp 1991) using a Model CEC 440HA Exeter Analytical elemental analyzer with a sensitivity of 2 to $4000 \mu \mathrm{g} \mathrm{C}$ and a precision of $\pm 2 \mu \mathrm{g}$ $\mathrm{C}$ or $0.3 \%$. A nutrient sample was collected from the filtrate in an acid-rinsed $60 \mathrm{ml}$ polycarbonate tube. Nutrient samples were analyzed for their concentration of phosphate (range 0.1 to $3 \mu \mathrm{M}$, precision $\pm 0.02 \mu \mathrm{M}$ or $5 \%$ ), nitrate/nitrite (range 0.5 to $30 \mu \mathrm{M}$, precision $\pm 0.05 \mu \mathrm{M}$ or $5 \%$ ) and ammonia (range 0.1 to $3 \mu \mathrm{M}$, precision $\pm 0.03 \mu \mathrm{M}$ or $5 \%$ ) on a Quik Chem 8000 flow-injection analyzer (Zellweger Analytics) (Johnson et al. 1985).

We also collected 3 replicate DOC samples of $40 \mathrm{ml}$ from the filtrate, and placed these in precombusted glass vials, sealed with acid-rinsed Teflon septa and 
then stored at $-20^{\circ} \mathrm{C}$. DOC samples were analyzed via high-temperature combustion with a slightly modified Shimadzu TOC-V carbon analyzer. The condensation coil was removed and the headspace of the internal water trap was reduced. The combustion tube contained $0.5 \mathrm{~cm}$ Pt pillows placed on top of Pt aluminum beads to improve peak shape and to reduce alteration of the combustion matrix throughout the run. Extensive conditioning of the combustion tube with repeated injections of low-carbon water (LCW) and deep seawater was essential to minimize machine blanks. After conditioning, the system blank was assessed with UVoxidized LCW. The system response was standardized daily with a 4-point calibration curve of potassium hydrogen phthalate solution in LCW. Each test sample was drawn into a $5 \mathrm{ml}$ injection syringe and acidified with $2 \mathrm{M} \mathrm{HCl}(1.5 \%)$ and sparged for $1.5 \mathrm{~min}$ with $\mathrm{CO}_{2}$-free gas; $100 \mu \mathrm{l}$ of sample was then injected into the $680^{\circ} \mathrm{C}$ combustion tube, with the resulting gas stream being passed through several water and halide traps. The $\mathrm{CO}_{2}$ in the carrier gas was then analyzed with a non-dispersive infrared detector and the resulting peak was integrated with Shimadzu chromatographic software. Injections for the same sample continued until at least 3 injections met the specified range of a standard deviation of 0.1 area counts, the coefficient of variation was $\leq 2 \%$ or the best 3 of 5 injections. All samples were systematically referenced against LCW, deep Sargasso Sea reference waters $(2600 \mathrm{~m})$, and surface Sargasso Sea water at every 6th analysis (Hansell \& Carlson 1998). The standard deviation of the deep and surface references $(\mathrm{n}=5$ each) was 1.0 and $0.8 \mu \mathrm{M} \mathrm{C}$, respectively, with the coefficient of variation ranging between 1 and $2 \%$ over the 5 independent analyses. Daily reference waters were calibrated with DOC Certified Reference Material (CRM) provided by D. Hansell (University of Miami).

Aggregate remineralization experiments. We conducted 2 aggregate remineralization experiments to compare remineralization rates between whole and fragmented aggregates. These experiments had a similar setup to the fragmentation experiment described above except for the addition of 11 bottles ( 4 whole, 4 fragmented, 3 control) that were sacrificed after a 3 to $5 \mathrm{~d}$ incubation period. These bottles were kept at sea surface temperature $\left(\sim 18^{\circ} \mathrm{C}\right)$ while rotating end-overend to keep marine snow in suspension but to reduce aggregation (in contrast to typical rolling tables, Shanks \& Edmondson 1989). A shipboard incubator (modified from Crocker \& Gotschalk 1997) was designed for this purpose. Following the incubation period, bottles were treated as described for the fragmentation experiment. We compared the amounts of solubilization and remineralization for whole versus fragmented aggregates by assessing changes in the pools of carbon. POC and DOC were directly measured and TOC was determined by addition (POC + DOC = TOC). Aggregate turnover times for each experiment were calculated by dividing aggregate POC content by the POC removal rate (normalized per aggregate).

For the first remineralization experiment (Expt 1), aggregates were resuspended in unfiltered seawater collected in Niskin bottles from the dive depth $(13 \mathrm{~m})$ and incubated for $3 \mathrm{~d}$. For the second remineralization experiment (Expt 2), aggregates were resuspended in $0.2 \mu \mathrm{m}$-filtered seawater and incubated for $5 \mathrm{~d}$. We collected this seawater in the Santa Barbara Channel, from $150 \mathrm{~m}$ depth to minimize the amount of labile DOC added. This seawater was gravity-filtered through a $142 \mathrm{~mm} 0.2 \mu \mathrm{m}$ nitrocellulose filter to remove bacteria. The Costar Membra-Fil filters provided a high flow rate, employing gentle filtration and reducing cell lysis (Carlson \& Ducklow 1996). While Membra-Fil filters initially leach a measurable amount of DOC, leaching was reduced to below detection levels by flushing with 21 of Milli-Q water followed by several liters of sample seawater prior to collecting the experimental filtrate.

Data analysis. The standard error for TOC in the remineralization experiments was determined by taking the square root of the sum-of-squares for the standard error of the measured parameters (i.e. POC and DOC). Normality of all data was assessed using a Shapiro-Wilk test. All data were normally distributed with the exception of nitrate/nitrite concentration, which was normalized via log-transformation. Differences between treatments were assessed using a 1-way ANOVA. Due to the small sample sizes we also ran Kruskal-Wallis non-parametric tests and found similar results.

\section{RESULTS AND DISCUSSION}

\section{Fragmentation experiment}

Several studies have demonstrated that marine snow aggregates can have elevated interstitial nutrient and DOC concentrations (Shanks \& Trent 1979, Kaltenbock \& Herndl 1992, Alldredge 2000) relative to surrounding seawater. This unique chemical environment results from the heterotrophic activity of attached biota and also potentially from slowed molecular diffusion due to the mucus and/or gel (transparent exopolymer particles, TEP) matrix of marine aggregates (Passow \& Alldredge 1995).

The marine snow used for the fragmentation experiment was largely composed of larvacean houses, probably discarded by Oikopleura spp. Larvacean house 
snow has a mucous structure but generally also contains a variety of other detrital material caught in the matrix. These aggregates were several millimeters in diameter and had an average POC:PON ratio of 6.8. Aggregates had an average dry weight of $145 \pm 35 \mu \mathrm{g}$ and a POC content of $0.2 \pm 0.1 \mu \mathrm{mol}$ aggregate ${ }^{-1}$. The POC content and dry weight of the sum of the daughter particles from fragmented aggregates were not significantly different from that of whole aggregates. However, in bottles with fragmented aggregates there was an immediate increase in DOC compared to both whole-aggregate and control bottles (ANOVA, $F_{2}=$ 68.140, p < 0.001) (Fig. 1A). The average increase (compared to whole aggregates) was $7.1 \%$ or $4.16 \mu \mathrm{mol} \mathrm{DOC} \mathrm{l}^{-1}$ (range $=3.3$ to $5.8 \mu \mathrm{mol} \mathrm{DOC} \mathrm{l}^{-1}$ ), which is equivalent to $0.12 \mu \mathrm{mol}$ DOC aggregate $^{-1}$. This interstitial DOC content is at the lower end of the range measured for a variety of aggregate types by Alldredge (2000). The DOC concentration in filtrate from the whole-aggregate bottles was not significantly different from that in the control bottles, and was similar to sampled surface seawater DOC concentration $\left(\sim 59 \mu \mathrm{mol} \mathrm{C}{ }^{-1}\right)$. Nitrate/nitrite concentrations in the filtrate from the control and whole-aggregate treatment were similar ( $p>0.05)$, but nitrate/nitrite increased significantly in the fragmented-aggregate treatment (ANOVA, $F_{2}=9.030, \mathrm{p}=0.003$ ) (Fig. 1B), amounting to $0.013 \mu \mathrm{mol}$ nitrate/nitrite per aggregate. This value reflects interstitial macronutrient concentrations within the lower range of previously reported values for marine snow collected off the California coast (Shanks \& Trent 1979) and the Northern Adriatic
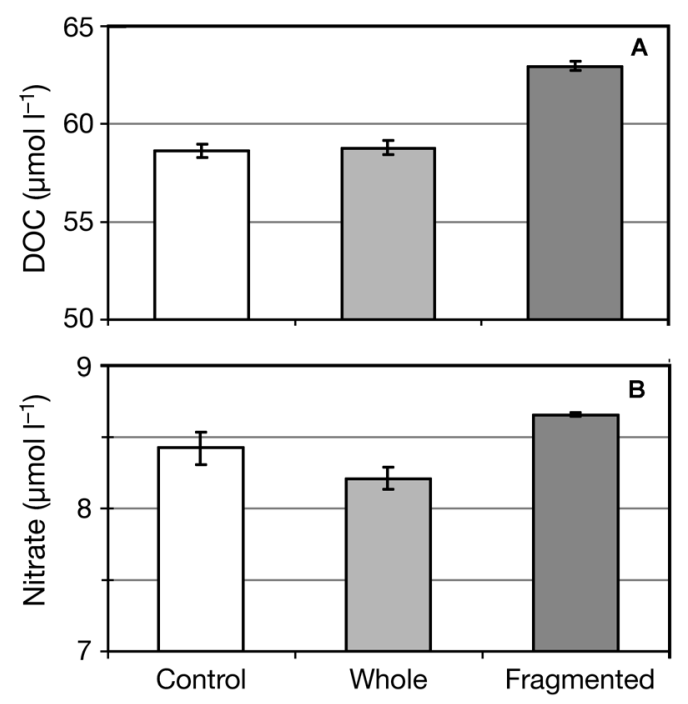

Fig. 1. Mean $( \pm 1 \mathrm{SE})$ filtrate concentration for control, whole and fragmented-aggregate treatments for (A) dissolved organic carbon (DOC) and (B) nitrate. Entire volume of each bottle was filtered immediately following aggregate or simulated aggregate (for control) addition
Sea (Kaltenbock \& Herndl 1992). Thus, it appears that fragmentation does release some, but likely not all, of the DOC and nitrate found in aggregate interstices. At near surface-water aggregate abundances of 1 to $100 \mathrm{l}^{-1}$ (Alldredge \& Silver 1988, Alldredge et al. 2002), aggregate fragmentation could increase DOC concentrations by approximately 0.1 to $10 \mu \mathrm{mol} \mathrm{l}^{-1}$ and nitrate concentrations by 0.01 to $1 \mu \mathrm{mol} \mathrm{l} \mathrm{l}^{-1}$.

The larvacean-house snow used in this experiment might be expected to have a higher concentration of interstitial nutrients due to slowing of diffusion by the mucous structure of the house. However, a similar release of DOC was also observed upon fragmentation for the fragile, diatom-based aggregates (see Fig. 2C) and detrital/fecal aggregates (see Fig. 3C) used in the bacterial degradation experiments. Such aggregate disruption may constitute a potentially important source of nutrients for free-living bacteria and contribute to microscale environmental patchiness.

This release of interstitial nutrients and DOC was not due to cell breakage, as the shear stress generated during handling was inadequate to rupture cell walls (Gotschalk \& Alldredge 1989). It is interesting that for whole aggregates the filtration process (during which filters ran dry) failed to result in an equivalent release of interstitial solutes to the filtrate (Fig. 1). Marine snow aggregates generally have very high porosity, ranging from 97 to $99.9 \%$ depending on aggregate size and type (Alldredge \& Gotschalk 1988). Due to its fractal, porous nature, marine snow has been assumed to readily exchange interstitial fluid with the external environment. Kiørboe \& Jackson (2001) modeled solute trails left by sinking marine snow aggregates and speculated that these trails could be an important source of nutrients for free-living bacteria. These solute plumes were also observed in the laboratory with artificial marine snow aggregates (Kiørboe et al. 2001). However, aggregates made from rolled phytoplankton cultures (Shanks \& Edmondson 1989) or agar, may not completely simulate natural aggregates that have more diverse origins and histories. The results of the present study suggest that natural aggregates are leaky, but that solutes are less readily lost from aggregate interstices than would be expected, perhaps slowed by the presence of gel-like TEP, which are often abundant in marine aggregates (Passow \& Alldredge 1995), or mucus in aggregates derived from zooplankton feeding structures.

\section{Aggregate remineralization experiments}

This is the first study to simultaneously monitor changes in POC and DOC in marine snow incubations. By tracking DOC concentration we were able to deter- 
Table 1. Results of 2 marine snow remineralization experiments comparing whole and fragmented aggregates, showing startand endpoint concentrations of particulate organic carbon (POC), dissolved organic carbon (DOC), and total organic carbon

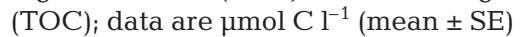

\begin{tabular}{|c|c|c|c|c|c|c|c|}
\hline & & \multicolumn{2}{|c|}{$\mathrm{POC}-$} & \multicolumn{2}{|c|}{$-\mathrm{DOC}-$} & \multicolumn{2}{|r|}{$-\mathrm{TOC}-$} \\
\hline & & Whole & Fragmented & Whole & Fragmented & Whole & Fragmented \\
\hline \multirow[t]{2}{*}{ Expt $1(3 \mathrm{~d})$} & Start & $12.2 \pm 1.4$ & $10.2 \pm 1.2$ & $73.1 \pm 1.3$ & $79.8 \pm 4.1$ & $85.3 \pm 1.9$ & $90.0 \pm 4.2$ \\
\hline & End & $4.1 \pm 1.2$ & $3.6 \pm 0.9$ & $68.8 \pm 0.3$ & $74.3 \pm 2.6$ & $72.9 \pm 1.2$ & $77.8 \pm 2.7$ \\
\hline \multirow[t]{2}{*}{ Expt $2(5 d)$} & Start & $39.2 \pm 4.4$ & $31.0 \pm 5.6$ & $54.5 \pm 0.4$ & $59.2 \pm 0.8$ & $93.7 \pm 4.5$ & $90.2 \pm 5.6$ \\
\hline & End & $23.9 \pm 3.6$ & $19.2 \pm 3.1$ & $54.8 \pm 0.5$ & $56.1 \pm 0.5$ & $78.7 \pm 3.6$ & $75.3 \pm 3.1$ \\
\hline
\end{tabular}

mine if POC solubilized to DOC was taken up by bacteria and thus address the biogeochemical fate of $\mathrm{C}$ associated with particles.

Aggregates used in Expt 1 were composed predominantly of diatoms (specifically Chaetoceros spp.) with minimal fecal and miscellaneous material. The low $\mathrm{C}: \mathrm{N}$ ratio of these aggregates is suggestive of freshly produced material. An average aggregate had $0.1 \pm 0.1 \mu \mathrm{mol}$ POC and a dry weight of $45 \pm$ $44 \mu \mathrm{g}$. The low material content and large size (3 to $4 \mathrm{~mm}$ ) of these aggregates was indicative of very high porosity. Over the course of the $3 \mathrm{~d}$ incubation period, POC decreased significantly in both the whole and fragmented treatments (ANOVA, $F_{5}=$ 10.224, $\mathrm{p}=0.001$ ) (Table 1, Fig. 2B). However, the magnitude of the decrease was similar for both treatments. The POC removed was sufficient to account for the complete loss of aggregate-associated POC plus some additional removal of background POC. The continued presence of visible aggregate material after $3 \mathrm{~d}$ also supports the notion of non-aggregate POC removal. While DOC generally declined (Table 1, Fig. 2C) during this experiment, the decrease was not significant for the fragmented-aggregate treatment. However, after $3 \mathrm{~d}$ the DOC concentration in the whole and fragmented treatments was similar and was significantly higher than the control (ANOVA, $F_{5}=4.081, \mathrm{p}=0.029$ ). In summary, for Expt 1 an average of 8.1 and $6.6 \mu \mathrm{mol}$ POC $\mathrm{l}^{-1}$ were removed from whole and fragmented treatments, respectively, compared to $2.2 \mu \mathrm{mol}$ POC $\mathrm{l}^{-1}$ in the control bottles over the $3 \mathrm{~d}$ incubation period. DOC concurrently decreased by an average of 4.3 and $5.5 \mu \mathrm{mol}$ DOC $\mathrm{l}^{-1}$ for the whole and fragmented treatments, respectively, compared with a removal of 2.6 $\mu \mathrm{mol}$ DOC $\mathrm{l}^{-1}$ in the control bottles. Thus, for Expt 1 an average of $\sim 12 \mu \mathrm{mol}$ TOC $1^{-1}$ was removed from both aggregate treatments, with the majority of this change being due to remineralization of aggregate POC (Fig. 2A,B). There was also a net decrease in DOC, which may be indicative of remineralization of background DOC as evident from the change in control bottles (Fig. 2C).
The aggregates used in Expt 2 had a much higher average POC content $(1.0 \pm 0.3 \mu \mathrm{mol})$ than those in Expt 1, but were similar in diameter (3 to $4 \mathrm{~mm}$, no dry weights available) and C:N ratio $(\sim 5)$. The dominant component of these aggregates was unidentifiable detrital material with some associated large fecal pellets, probably produced by Euphausia pacifica (euphausiids). POC was significantly greater in both aggregate treatments than in the control at the start and end of the incubation (ANOVA, $F_{5}=12.123, \mathrm{p}<$ 0.042) (Fig. 3B). POC decreased significantly over the $5 \mathrm{~d}$ experiment in the whole aggregate treatment and in the fragmented treatment (ANOVA, $F_{5}=12.123, \mathrm{p}<$ 0.040 ) by an average of 15.3 and $11.8 \mu \mathrm{mol} \mathrm{POC} \mathrm{l}^{-1}$,

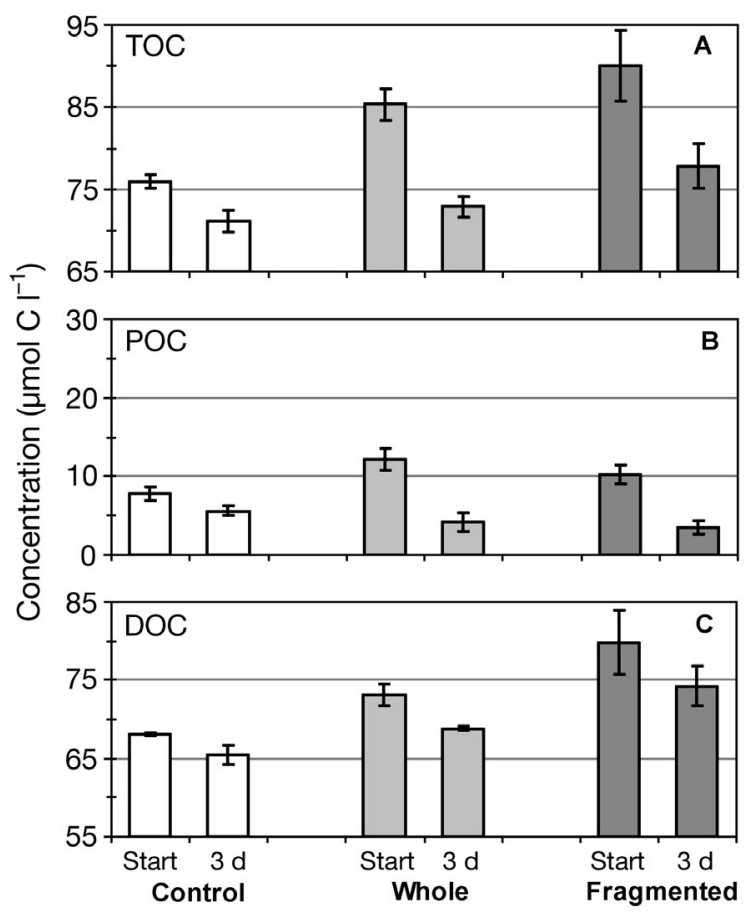

Fig. 2. Mean $( \pm 1 \mathrm{SE})$ concentration of organic carbon in control, whole and fragmented-aggregate (predominant diatoms) treatments at Time 0 and after $3 \mathrm{~d}$ in first remineralization experiment 1 (Expt 1). (A) Total organic carbon (TOC); (B) particulate organic carbon (POC); (C) dissolved organic carbon (DOC) 


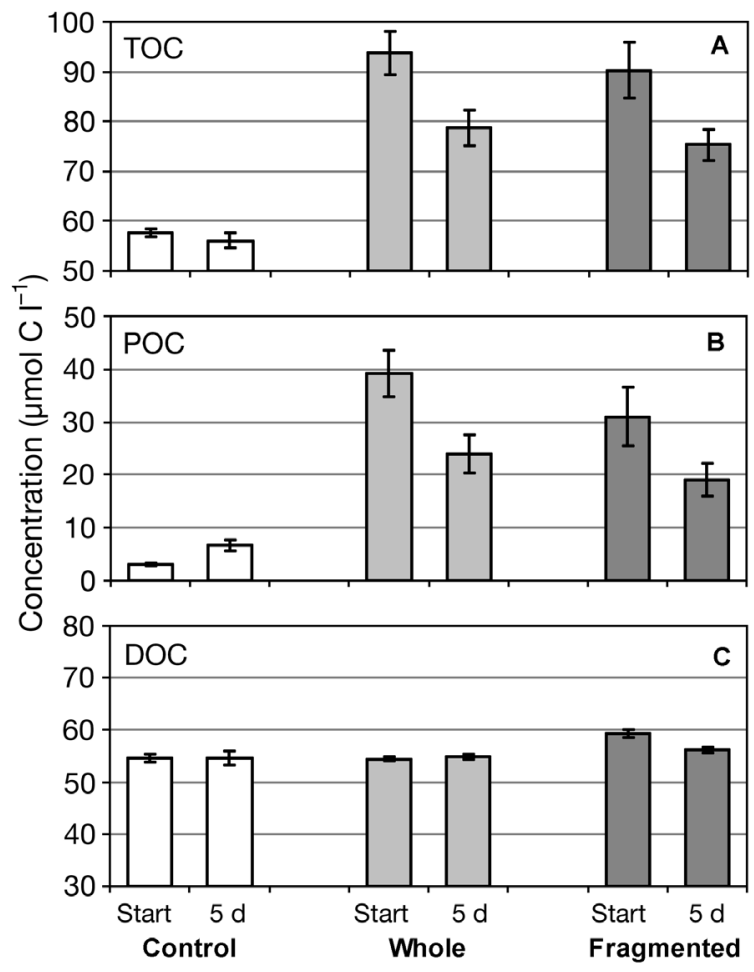

Fig. 3. Mean ( $\pm 1 \mathrm{SE}$ ) concentration of organic carbon in control, whole and fragmented-aggregate (unidentifiable detrital/fecal material) treatments at Time 0 and after $5 \mathrm{~d}$ in second remineralization experiment (Expt 2)

respectively (Table 1), while POC increased in the control. DOC concentration did not change significantly in either the control or the whole-aggregate treatment during the incubation period (Fig. 3C). In the fragmented-aggregate treatment initial DOC concentration was greater than both the control and wholeaggregate treatment at Time 0 (ANOVA, $F_{5}=13.554$, $\mathrm{p}<0.001)$ due to release during fragmentation and DOC decreased significantly over time $\left(\right.$ ANOVA, $F_{5}=$ 8.167, $\mathrm{p}=0.003$ ) by $3.1 \mu \mathrm{mol}$ POC $\mathrm{l}^{-1}$. The removal of an average of $\sim 15 \mu \mathrm{mol} \mathrm{TOC} 1^{-1}$ in both aggregate treatments indicates that $\mathrm{POC}$ was being remineralized. All DOC added to the culture as a result of fragmentation or solubilization was removed over $5 \mathrm{~d}$; however, no background DOC was removed (Fig. 3C), as indicated by stable values in the control bottles. This is not surprising since the background seawater was collected from $150 \mathrm{~m}$ and probably had little labile DOC. Stable DOC and reduced TOC indicate that solubilized POC was rapidly utilized (i.e. within 5 d) primarily by attached biota, as aggregates were incubated in $0.2 \mu \mathrm{m}$-filtered seawater where free-living bacteria were reduced $\left(\sim 10^{4}\right.$ cells ml $\left.{ }^{-1}\right)$. This suggests a tighter coupling between solubilization and uptake by aggregate-associated biota than has often been observed (e.g. Cho \& Azam 1988).
Overall, POC solubilization did not appear to be affected by aggregate fragmentation. In a similar study using fluorescently labeled substrates, no significant difference was found for glucosidase or animopeptidase activity between whole versus fragmented aggregates (data not shown). Ploug et al. (1999) suggested that attached bacterial abundance may depend on aggregate surface area. However in our study, the increased colonizable surface area of fragmented aggregates relative to whole aggregates did not affect POC removal, suggesting that surface area may not be a limiting factor.

Although POC consumption was similar for both experiments, ranging from 0.6 to $0.9 \mu \mathrm{mol}$ POC aggregate $^{-1} \mathrm{~d}^{-1}$, turnover time varied due to differing aggregate POC content. The aggregates with the lowest POC content would turnover in 1.6 to $2.2 \mathrm{~d}$, potentially while still in the mixed layer (applying the sinking rates of Alldredge \& Gotschalk 1988), while turnover times for aggregates with higher POC content would be longer (9.0 to $9.6 \mathrm{~d}$ ). Nevertheless, all these turnover times are much more rapid than historical estimates based on attached bacterial production measurements, which resulted in calculated POC turnover times of months to years (Eppley \& Peterson 1979, Karl et al. 1988, Smith et al. 1992). Improved incubation techniques (Ploug \& Grossart 1999) have led to higher measurements of aggregate POC turnover (Ploug \& Grossart 2000) similar to those found in the present study. Studies to date have used proxy measurements to assess carbon turnover. The present study has gone further by directly measuring the removal of DOC derived from the solubilization of aggregate material. This DOC was readily utilized, within 3 to $5 \mathrm{~d}$, indicating that a substantial portion of the aggregate $\mathrm{C}$ was labile to semi-labile.

\section{CONCLUSION}

Aggregate fragmentation results in an immediate release of interstitial DOC and macronutrients to surrounding seawater, making them available to freeliving biota. Surprisingly, solubilization rates were similar for both whole and fragmented aggregates, suggesting that aggregate surface area may not regulate bacterial colonization. Thus, fragmentation can decrease the flux of aggregate-associated $\mathrm{C}$ by both releasing interstitial DOC and reducing daughter-particle sinking rate, but increased particle surface area does not appear to accelerate POC degradation. However, the longer residence time of daughter fragments in surface waters where bacterial abundance and activity are elevated should result in reduced $\mathrm{C}$ flux and greater recycling of aggregate-associated $\mathrm{C}$ in the upper layers of the ocean. 
Acknowledgements. We thank S. Stone, C. Swan, J. Sprague, the Marine Science Institute Analytical Laboratory, and the captain and crew of the RV 'Point Sur' for laboratory and field assistance. R. Ross and J. Yen provided helpful comments on the manuscript. This research was funded by NSF grants OCE-0296101 (to A.L.A. and J. Yen) and OCE-0221825 (to C.A.C.).

\section{LITERATURE CITED}

Alldredge AL (1993) Production of heterotrophic bacteria inhabiting marine snow. In: Kemp PF, Sherr BF, Sherr EB, Cole JJ (eds) Handbook of methods in aquatic microbial ecology. Lewis Publishers, Boca Raton, FL, p 423-431

Alldredge AL (2000) Interstitial dissolved organic carbon (DOC) concentrations within sinking marine aggregates and their potential contribution to carbon flux. Limnol Oceanogr 45:1245-1253

Alldredge AL, Gotschalk CC (1988) In situ settling behavior of marine snow. Limnol Oceanogr 33:339-351

Alldredge AL, Silver MW (1988) Characteristics, dynamics and significance of marine snow. Prog Oceanogr 20:41-82

Alldredge AL, Cowles TJ, MacIntyre S, Rines JEB and 6 others (2002) Occurrence and mechanisms of formation of a dramatic thin layer of marine snow in a shallow Pacific fjord. Mar Ecol Prog Ser 233:1-12

Banse K (1995) Zooplankton-pivotal role in the control of ocean production. ICES J Mar Sci 52:265-277

Carlson CA, Ducklow HW (1996) Growth of bacterioplankton and consumption of dissolved organic carbon in the Sargasso Sea. Aquat Microb Ecol 10:68-85

Cho BC, Azam F (1988) Major role of bacterial in biogeochemical fluxes in the ocean's interior. Nature 332: 441-443

Crocker KM, Gotschalk C (1997) A simple seawater-powered plankton wheel. J Plankton Res 19:155-158

Dilling L, Alldredge AL (2000) Fragmentation of marine snow by swimming macrozooplankton: a new process impacting carbon cycling in the sea. Deep-Sea Res I 47: $1227-1245$

Eppley RW, Peterson BJ (1979) Particulate organic-matter flux and planktonic new production in the deep ocean. Nature 282:677-680

Goldthwait SA, Yen J, Alldredge AL, Brown J (2004) Quantification of marine snow fragmentation by swimming euphausiids. Limnol Oceanogr 49:940-952

Gotschalk CC, Alldredge AL (1989) Enhanced primary production and nutrient regeneration within aggregated marine diatoms. Mar Biol 103:119-129

Hansell DA, Calson CA (1998) Deep ocean gradients in dissolved organic carbon concentrations. Nature 395:263-266

Johnson KS, Petty RL, Thomsen J (1985) Flow injection analysis for seawater micronutrients. In: Zirino A (ed) Mapping strategies in chemical oceanography. American Chemical Society, Washington, DC, p 7-30

Kaltenbock E, Herndl GJ (1992) Ecology of amorphous aggregations (marine snow) in the northern Adriatic Sea. 4. Dis-

Editorial responsibility: Otto Kinne (Editor-in-Chief),

Oldendorf/Luhe, Germany solved nutrients and the autotrophic community associated with marine snow. Mar Ecol Prog Ser 87: $147-159$

Karl DM, Knauer GA, Martin JH (1988) Downward flux of particulate organic matter in the ocean: a particle decomposition paradox. Nature 332:438-441

Kiørboe T, Jackson GA (2001) Marine snow, organic solute plumes, and optical chemosensory behavior of bacteria. Limnol Oceanogr 46:1309-1318

Kiørboe T, Ploug H, Thygesen UH (2001) Fluid motion and solute distribution around sinking aggregates. I. Smallscale fluxes and heterogeneity of nutrients in the pelagic environment. Mar Ecol Prog Ser 211:1-13

Lampitt RS, Noji T, von Bodungen B (1990) What happens to zooplankton fecal pellets? Implications for material flux. Mar Biol 104:15-23

Martin JH, Knauer GA, Karl DM, Broenkow W (1987) VERTEX: carbon cycling in the northeast Pacific. Deep-Sea Res 34:267-285

Passow U, Alldredge AL (1995) Aggregation of a diatom bloom in a mesocosm: the role of transparent exopolymer particles (TEP). Deep-Sea Res II 42:99-109

Ploug H, Grossart HP (1999) Bacterial production and respiration in suspended aggregates - a matter of the incubation method. Aquat Microb Ecol 20:21-29

Ploug H, Grossart HP (2000) Bacterial growth and grazing on diatom aggregates: Respiratory carbon turnover as a function of aggregate size and sinking velocity. Limnol Oceanogr 45:1467-1475

Ploug H, Grossart HP, Azam F, Jørgensen BB (1999) Photosynthesis, respiration, and carbon turnover in sinking marine snow from surface waters of Southern California Bight: implications for the carbon cycle in the ocean. Mar Ecol Prog Ser 179:1-11

Ruiz J (1997) What generates daily cycles of marine snow? Deep-Sea Res I 44:1105-1126

Shanks AL, Edmondson EW (1989) Laboratory-made artificial marine snow: a biological model of the real thing. Mar Biol 101:463-470

Shanks AL, Trent JD (1979) Marine snow: microscale nutrient patches. Limnol Oceanogr 24:850-854

Sharp JH (1991) Total mass and particulate carbon, nitrogen, and phosphorus. In: Hurd DC, Spencer DW (eds) Marine particles: analysis and characterization. American Geophysical Union, Washington, DC, p 87-91

Smith DC, Simon M, Alldredge AL, Azam F (1992) Intense hydrolytic enzyme activity on marine aggregates and implications for rapid particle dissolution. Nature 359: 139-142

Steinberg DK, Silver MW, Pilskaln CH (1997) Role of mesopelagic zooplankton in the community metabolism of giant larvacean house detritus in Monterey Bay, California, USA. Mar Ecol Prog Ser 147:167-179

Unanue M, Azua I, Arrieta JM, Labirua-Iturburu A, Egea L, Iriberri J (1998) Bacterial colonization and ectoenzymatic activity in phytoplankton-derived model particles: cleavage of peptides and uptake of amino acids. Microb Ecol 35:136-146

Submitted: May 3, 2004; Accepted: June 28, 2005 Proofs received from author(s): November 22, 2005 